\title{
Diyabetli Bireylere Hangi Beslenme Modeli Önerilmeli?
}

\section{Which Nutrition Model Should be Recommended to Individuals with Diabetes?}

\section{Cemile İdiz ${ }^{1}$}

Geliş tarihi/Received: 11.01.2019 • Kabul tarihi/Accepted: 21.04.2019

\section{ÖZET}

Bin dokuz yüzlü yılların özellikle ikinci çeyreğinden itibaren başlayan ve günümüze dek artarak devam eden çalışmalarla "diyabet yönetiminde en etkili beslenme modeli” arayışı sürmektedir. Bu konudaki araştırmalar daha çok "çok düşük kalorili diyetler”, “düşük karbonhidratlı ve düşük yağlı diyetler”, "vejetaryen ya da vegan beslenme”, "DASH beslenme modeli” ve "Akdeniz tipi beslenme modeli” üzerine yoğunlaşmıştır. Bu derlemede, bahsi geçen diyet ve beslenme modellerinin diyabet tedavisindeki yerlerinin bilimsel literatür doğrultusunda incelenmesi hedeflenmiştir. Çeşitli kılavuzlarda, Akdeniz, DASH ve bitkisel bazlı diyetlerin, diyabetik bireyler ile ilişkili olumlu sonuçları nedeniyle sağlıklı beslenme modellerine örnek teşkil ettiği vurgulanmaktadır. Düşük karbonhidratlı diyetlerin rolü ise henüz net değildir. Sonuç olarak bireyselleştirilmiş beslenme planı, belirli beslenme modellerinin önerilmesinden ziyade kişisel tercihler, ihtiyaç ve hedefler üzerine odaklanmalıdır.

Anahtar kelimeler: Beslenme modelleri, diyabet, düşük kalori, DASH

\begin{abstract}
There have been increasing number of studies, which have been looking for "most effective nutrition model in the management of diabetes" since the second quarter of the 1900s. Researches on this subject mostly focuses on "very low calorie diets", "low-carbohydrate and low-fat diets", "vegetarian or vegan nutrition”, "DASH dietary model" and "Mediterranean diet model". In this review, it is aimed to examine the place of dietary and nutritional models in the treatment of diabetes with highlight of the scientific literature. In various guidelines, it is emphasized that Mediterranean, DASH and plant-based diets are examples of healthy nutrition models due to the positive results associated with diabetic individuals. The role of low-carbohydrate diets for diabetes is not clear yet. As a result, the personalized diet plans should focus on individual's preferences, needs and intentions rather than the recommendation of certain nutritional models.
\end{abstract}

Keywords: Nutrition models, diabetes, low calorie, DASH

\section{GíRIŞ}

İnsülinin keşfinden önce (1921) diyabetin tedavi seçenekleri, açlık diyetleri ve çok düşük karbonhidrat $(\mathrm{KH})$ içeren diyetlerden oluşmuş ve KH kısıtlaması önerileri 1960’ll ylllara kadar devam etmiştir (1).
Beslenme modelleriyle ilişkili yayınlar incelendiğinde, yaklaşık yüz yıl öncesine dayanan araştırmalar göze çarpmaktadır. Örneğin Rabinowitch'in 1930 yılında yayınlanan makalesinde yüksek KH'li ve düşük

1. İletişim/Correspondence: İstanbul Üniversitesi, İstanbul Tıp Fakültesi, İç Hastalıkları Anabilim Dalı, İstanbul, Türkiye

E-posta: cemilecakmakci@mynet.com • i https://orcid.org/0000-0001-6635-5996 
kalorili diyetlerin diyabet tedavisindeki etkinliği sorgulanmaktadır (2). Günümüzde halen diyabet yönetiminde en etkili beslenme modeli arayışının devam etmesi nedeniyle bu derlemede, diyabet tedavisinde rolü en çok irdelenen beslenme modelleri bilimsel literatür doğrultusunda incelenmiştir.

\section{Çok Düşük Kalorili Diyetler}

Çok düşük kalorili diyetler, günlük <800 kkal enerji sağlayan programlardır (3). 1985 yılında Henry et al. (4) tarafından yapılan bir çalışmada, tip 2 diyabetli 30 bireye 40 gün boyunca enerji alımı 330 kkal/gün olan diyet verilmiş ve ortalama açlık plazma glukozu başlangıçta $297 \pm 13 \mathrm{mg} / \mathrm{dL}$, 10. günde $158 \pm 10 \mathrm{mg} /$ $\mathrm{dL}, 40$. günde ise $138 \pm 9 \mathrm{mg} / \mathrm{dL}$ olarak saptanmıştır. $\mathrm{Bu}$ çalışmada dikkat çeken nokta; açlık glukozunda saptanan azalmanın \%87'sinin ciddi vücut ağırlık kaybından önce gerçekleşmiş olmasıdır (4). Bu noktada "ikiz siklus hipotezi” gündeme gelmektedir. Bazı araştırmacılara göre, biliopankreatik diversiyondan bir hafta gibi kısa bir süre sonra kan glukoz seviyelerinin normale dönmesi, sadece ameliyatın inkretin hormonlar üzerine olan etkisine bağlanmamakta, ikiz siklus hipoteziyle muhtemel mekanizma açıklanarak tip 2 diyabetin geri dönüşüm etiyolojisi üzerinde durulmaktadır (5).

İkiz siklus hipotezi, ektopik yağ birikimini harekete geçiren mekanizmaları açıklamaktadır. Bu hipoteze göre uzun süreli aşırı enerji alımı, lipogenez yoluyla karaciğerde yağ birikimini hızlandırmaktadır. Ayrıca insülin direnci ve hepatik glukoz üretimi daha da artmaktadır. Zamanla, bu durum kan glukoz düzeylerinin yükselmesine ve hiperinsülinemiye neden olur. Ayrıca karaciğerdeki aşırı yağ birikimi çok düşük dansiteli lipoprotein (very low density lipoprotein [VLDL])'de bir artışa yol açması nedeniyle pankreatik adacık hücreleri dahil olmak üzere tüm dokuların yağ içeriği artar. Adacık hücrelerindeki aşırı yağ birikimi, besinlere yanıt olan akut insülin sekresyonunu olumsuz etkiler; bu da postprandiyal hiperglisemiye ve nihayetinde klinik diyabetin başlamasına neden olur (6).
Tip 2 diyabete özellikle karaciğer ve pankreastaki aşırı yağ birikiminin neden olduğunu öne süren ikiz siklus hipotezi, yapılan bir çalışmada $600 \mathrm{kkal} /$ gün enerji içeren diyetle negatif enerji dengesi sağlanarak test edilmiştir. Diyabet süresi 4 yıldan kısa olanların dahil edildiği çalışmada, insülin direnci ve karaciğer yağ içeriği 7 gün içinde normalize edilmiş, pankreatik yağ 8. haftada azalmış, beta hücre fonksiyonu normale doğru artmıştır (7). Buna karşın, Murakimi et al. (8), pankreastaki ektopik yağ birikiminin beta hücre apoptozunu indüklediği ve diyabet gelişimine yol açtığı yaklaşımını test etmek amacıyla yaptıkları ve 2017 yılında yayınlanan çalışmalarında, diyabeti olan ve olmayan bireylerdeki intrapankreatik yağın $\beta$ ve a hücre kütlesi üzerindeki etkilerini incelemişler ve sonuç olarak diyabeti olan ve olmayan bireylerin intrapankreatik yağ alanı ölçümleri arasında anlamlı bir fark saptamadıklarını bildirmişlerdir. Ayrıca, bu çalışmada intrapankreatik yağ alanı ile glikolize hemoglobin ya da $\beta$ ve a hücre alanları arasında da bir ilişki bulunmamıştır (8).

Diğer taraftan 1970’lerde çok düşük kalorili diyet uygulayan en az 60 kişi hayatını kaybetmiştir. Vücut ağırlık kaybından önce sağlıklı olan ve bu diyetlerin uzun süreli kullanımı sonrasında aniden ventriküler aritmigeçiren 17kişiüzerindekapsamlı değerlendirme yapılmış ve protein-enerji yetersizliği veya elektrolit anormalliklerinin bu bireylerin ani ölümlerinde rol oynamış olabileceği düşünülmüştür (9). Çok düşük kalorili diyetlerin etkisini değerlendirmek adına daha sonraki yıllarda yapılan çalışmalarda, bu bilgi dikkate alınarak beslenme planları oluşturulmuştur (10). $\mathrm{Bu}$ diyetlerin, hastaların yakın takibinin yapılacağı tıbbi bir ortamda ve deneyimli hekim kontrolünde uygulanmasının güvenilir olduğu vurgulanmaktadır (9).

Lean et al. (11), tip 2 diyabette çok düşük kalorili diyetin uzun dönem sonuçlarını değerlendirmek adına Diyabet Remisyon Klinik Çalışması’nı (Diabetes Remission Clinical Trial [DiRECT]) tasarlamışlardır. Araştırmaya son 6 yll içinde tip 2 diyabet tanısı alan, beden kütle indeksi (BKI) $27-45 \mathrm{~kg} / \mathrm{m}^{2}$ olan, insülin tedavisi almayan, 20-65 yaş arası bireyler 
dahil edilmiştir. Müdahale grubunda (n=149) tüm oral antidiyabetik ilaçlar (OAD) ve antihipertansifler çalışmanın ilk günü kesilmiş, 3-5 ay boyunca 825$853 \mathrm{kkal} /$ gün formüla diyet $\% 59 \mathrm{KH}, \% 13$ yağ, \%26 protein, \%2 lif) uygulanmış ve kademeli olarak yeniden beslenmeye geçiş (2-8 hafta) (\%50 KH, \%35 toplam yağ ve \%15 protein) sağlanmıştır. Çalışmanın birinci yll verileri değerlendirildiğinde diyabet remisyon oranının kontrol grubunda $(n=149) \% 4$ ve müdahale grubunda \%46 olduğu saptanmıştır. Yoğun yaşam tarzı değişikliğiyle diyabet remisyonunu değerlendiren Diyabette Sağlık için Eylem (Action for Health in Diabetes [LOOK AHEAD]) çalışmasında ise 1200-1800 kkal/gün enerji alımı ile bireylerin birinci ylldaki remisyon oranlarının \%11.5 düzeyinde olduğu saptanmıştır (12).

Çok düşük kalorili diyetlerin diyabet remisyonu üzerine etkileri değerlendirilmeye devam ederken kılavuzlar bu konuda temkinli davranmaktadır. Uluslararası Diyabet Federasyonu (International Diabetes Federation [IDF]) 2017 yılı önerilerinde, tip 2 diyabeti olan fazla kilolu ve obez hastalarm günlük enerji alımını 500-600 kkal azaltması ve mümkünse düşük enerjili diyet (günde 800-1200 kkal) uygulamalarına yardımcı olacak bir diyetisyene yönlendirilmeleri gerektiği vurgulanmaktadır (13). Amerikan Diyabet Birliği (American Diabetes Association [ADA]) kllavuzunda ise vücut ağırlık kaybının, bireysel tedavi yaklaşımı ile günlük enerji alımından 500-750 kkal azaltılması veya genel olarak kadınlar için 1200-1500 kkal/gün ve erkekler için 1500-1800 kkal/gün olan yaşam tarzı programlarının sürdürülmesi ile sağlanabileceği bilgisine yer verilmiştir (14). Diyabet Diyetisyenliği Derneği tarafindan 2019 yllında yayınlanan "Diyabetin Önlenmesi ve Tedavisinde Kanıta Dayalı Beslenme Tedavisi Rehberi”'nde çok düşük kalorili diyetlerle (<800 kkal/gün), kısa süre içinde >\%5 vücut ağırlık kaybı sağlanması hedeflenen bireylerin özenle belirlenmesi ve uygulamaların yakın klinik izlem altında olması gerektiği belirtilmiştir (15).

\section{Düşük Karbonhidratlı ve Düşük Yağlı Diyetler}

Snoorgaard et al. (16), KH kisitlamasinin tip 2 diyabetteki etkinliğini değerlendirmek amacıyla yapmış oldukları ve 2017 yılında yayınlanmış olan bir meta analiz kapsaminda düşük-orta KH'li diyetlerle (<\%45), yüksek KH' li diyetlerin (\%4560) kıyaslandığı on randomize çalışma verisini $(n=1376)$ incelemişlerdir. Meta analiz sonucunda, $\mathrm{KH}$ kısıtlamasının tip 2 diyabette glisemik kontrol üzerinde kısa vadede (3-6 ay) izokalorik yüksek KH’li diyetten (\%45-60) daha büyük bir etkiye sahipken, uzun vadede (>12 ay) HbA1c'nin iki grupta benzer olduğu saptanmıştır. Bu durumun diyete uyumda azalmayla ilişkili olabileceği, bağırsak mikrobiyotasında ki değişikliklerden veya kademeli adaptif mekanizmalardan kaynaklanabileceği düşünülmüştür. Ayrıca tüm çalışma sürelerinde izokalorik iki diyetin de vücut ağırlığı, LDL kolesterol ve yaşam kalitesi üzerinde benzer etkileri olduğu gözlenmiştir (16).

Tay et al.(17) tarafından tip 2 diyabetli bireylerde düşük ve yüksek KH'li diyetin etkilerinin değerlendirildiği randomize çalışmada, katılımcılara 2 yıl hipokalorik diyet ( $<\% 10$ doymuş yağ $)+180 \mathrm{dk} /$ hafta egzersiz planı uygulanmıştır. 2018 yılında yayınlanan bu çalışmada, düşük KH’li diyet (KH \%14, protein \%28, yağ \%58) grubu (n=33) ve yüksek KH'li (KH \%53, protein $\% 17$, yă \%30) diyet grubunun ( $=28)$ bulguları klyaslandığında düşük KH'li diyet grubunda, diyabet ilacı kullanımı, glisemik değişkenlik ve trigliserit (TG) düzeylerinde anlamlı azalma, yüksek dansiteli lipoprotein (HDL) kolesterol seviyesinde ise anlamlı artış saptanmasına karşın vücut ağırlık kaybı, vücut yağ kaybı, kan basıncı, HbA1c, açlık glukozu ve LDL kolesterol düzeylerinde iki grup arasında anlamlı fark saptanmamıştır (17).

Diyet enerjisinin $\mathrm{KH}$ ve yağlardan karşılanacak oranlarının azaltılması, enerjinin proteinlerden karşlanacak oranının artmasına neden olduğundan bu diyet modelinin uzun dönemde böbrek fonksiyonlarına etkisi düşük KH’li diyetlerle ilgili 
endişe duyulan konulardan birisi olmuştur (16). Bu konuyla ilgili yapılan bir çalışmada bir gruba ( $n=58)$ $<50$ g/gün KH (\%14 KH, \%28 protein, \%58 yağ) içeren düşük KH’li diyet ve diğer gruba $(n=57)$ ise yüksek KH’li (KH \%53, protein \%17, yağ \%30) hipokalorik diyet (eksi 500-1000 kkal/gün) uygulanarak katılımcılar 12 ay süreyle takip edilmişlerdir. Çalışma sonunda serum kreatinin ve glomerüler filtrasyon hızı (eGFR) düzeyleri açısından gruplar arasında anlamlı fark saptanmamıştır (18). Ancak sağlıklı beslenmek için yetişkinlere önerilen 0.8-1 g/kg/gün protein alımının düşük KH grubunda $1.3 \mathrm{~g} / \mathrm{kg} /$ gün olması dikkat çeken noktalardandir (16).

Diyabet kontrolünde düşük yağlı diyetin düşük KH’li diyete göre üstünlüğünün olup olmadığı konusunda birçok çalışma yapılmış ve bu çalışmaların bir kısmında düşük KH’li diyetin daha iyi sonuçlar verdiği gözlenirken çalışmaların bir kısmı ise düşük yağlı diyetler lehine sonuçlar vermiştir. Örneğin, Diyabeti Önleme Programı (Diabetes Prevention Program [DPP]) çalışmasının 1. yllında diyabet riski yüksek bireylerin vücut ağırlığında, en çok yüksek KH'li, yüksek lifli ve düşük yağlı diyetle azalma sağlandığı saptanmıştır (19). Benzer şekilde Finlandiya Diyabet Önleme Çalışması'nın (Finish Diabetes Prevention Study) 3. yllında, diyabet riski yüksek bireylerde vücut ağırlığında sağlanan azalmanın, yüksek yağlldüşük KH’li diyet tüketenlere kıyasla düşük yağlı diyet (yağ<\%30) tüketenlerde daha fazla olduğu ve ayrıca diyabet insidansının bu grupta daha düşük olduğu saptanmıştır (20). Diğer taraftan Miller et al. (21), yeni tanı alan ve 8 yll takip edilen tip 2 diyabetlilerde, düşük KH’li Akdeniz diyetinin $(<\% 50$ $\mathrm{KH}, \geq \% 30$ yağ), düşük yağlı diyete (<\%30 yağ) kıyasla ilaca başlama süresini geciktirdiğini bildirmişlerdir. Meckling et al. (22) ise yapmış oldukları bir çalışmada fazla kilolu ya da obez bireylerde 10 haftalık takip sonucu, düşük yağlı diyet (\%17.8 yağ) ve düşük KH’li diyet ( $\mathrm{KH} \mathrm{\% 15.4)} \mathrm{kıyaslandığında,} \mathrm{iki} \mathrm{diyetin} \mathrm{de}$ vücut ağırlığı, vücut yağ kaybı, sistolik ve diyastolik kan basıncı üzerine eşit derecede etkili olduğunu saptamış olmakla birlikte düşük KH’li diyet grubunda sirküle insülin konsantrasyonlarının anlamlı şekilde düşük olduğunu bildirmişlerdirdir (22). Bir başka çalışmada ise düşük KH'li diyet (KH \%20) uygulayan tip 2 diyabetli bireylerin yaşam kalitesi skorları 1 . yılda anlamlı şekilde yükselirken, düşük yağlı diyet (KH \%55-60, $\leq \% 30$ yağ) uygulayanlarda değişiklik saptanmamıştır. Her iki gruptaki tip 2 diyabetli bireylerin vücut ağırlığındaki azalma ise benzer bulunmuştur (23). Jonasson et al. (24), altı ay boyunca düşük KH'li (KH \%20) veya düşük yağlı (KH \%55-60, $\% 30$ yağ) diyet uygulayan grupların vücut ağırlık kayıplarının benzer olduğunu, KH’si kısıtlı diyetin düşük dereceli inflamasyon üzerine olumlu etki gösterdiğini saptamışlardır.

\section{Vejetaryen ya da Vegan Beslenme}

Gözlemsel çalışmalarda, vejetaryenlerdeki tip 2 diyabet oranının, vejetaryen olmayanların yaklaşı olarak yarısı kadar olduğu saptanmıştır. Düşük yağlı vegan diyetlerin glisemik kontrol üzerindeki etkisi, temelde vücut ağırlık kaybına atfedilmekle beraber, doymuş yağın, yüksek glisemik indeksli ve yüksek glisemik yüklü besin tüketiminin azaltılmasının, diyet lifi ve bitkisel protein alımının artması ya da intramiyoselülerlipitkonsantrasyonununazalmasının da glisemi üzerine etkili olduğu düşünülmektedir (25). n-3 yağ asitlerinin, demir (Fe), çinko (Zn), kalsiyum (Ca) minerallerinin, $D$ ve $B_{12}$ vitaminlerinin yetersizliği bu diyetlerle ilgili endişe kaynakları iken düşük doymuş yağ ve kolesterol alımı ile yüksek lif ve fitokimyasal alımı ise bu beslenme modelinin artıları olarak gösterilmektedir. Bazı vakalarda suplemanlar ya da zenginleştirilmiş besinlerin, besin ögelerinin karşılanmasını destekleyebileceği vurgulanmakta, özellikle $B_{12}$ vitamini suplemantasyonunun tüm vejetaryen bireylere uygulanması gerekliliğinin altı çizilmektedir $(26,27)$.

Bu konuda yapılan en uzun süreli araştırmalardan biri olan ve 2009 yılında yayınlanan çalışmalarında, Barnard et al. (28) düşük yağlı vegan diyetle ( $n=49)$, geleneksel diyabetik diyetin (2003 ADA önerilerine 
göre) (n=50) tip 2 diyabet kontrolündeki etkinliğini değerlendirmişlerdir. Çalışma sonunda günlük enerji alımı, vücut ağırlığı, BKİ, bel çevresi, kalça çevresi değerleri ile HbA1c, C-reaktif peptid, total ve LDL kolesterol düzeyleri iki grupta da anlamlı şekilde azalırken gruplar arasında anlamlı fark bulunmamıştır (28). Yine aynı araştırmacıların 2018 yllında yayınlanan ve tip 2 diyabette vegan diyetin rolünü inceleyen çalışmalarında bir gruba $(n=24)$ porsiyon kontrolü eğitimi ve bireyselleştirilmiş tıbbi beslenme tedavisi (\%50 KH (166 g), \%21 protein, \%30 yağ) uygulanmış, diğer gruba $(n=21)$ düşük yağlı vegan diyet (\%71 KH (265 g), \%14 protein, \%18 yağ) verilmiştir. 20 haftalık takip sonucunda, günlük enerji alımı, vücut ağırlığı, BKİ değerleri ile HbA1c, LDL kolesterol düzeyleri iki grupta da anlamlı şekilde azalırken gruplar arasında anlamlı fark bulunmamıştır (29).

Vejetaryen beslenme modelinin tip 2 diyabetli bireylerde yaşam kalitesi, ruh hali ve yeme davranışları üzerine etkisinin değerlendirildiği bir çalışmada, vejetaryen grup $(n=37)$ ve kontrol grubu (n=37) 24 hafta boyunca takip edilmiştir. Çalışma sonucunda her iki diyet, yaşam kalitesi ve ruh hali üzerinde olumlu bir etki yaratmış ancak, vejetaryen diyetin pozitif etkisi daha fazla bulunmuştur. Bu durumun, reseptör dinamikleri ve nörotransmitter sentez hızlarındaki farklılıkların etkisinden kaynaklanabileceği düşünülmüştür (30).

\section{DASH Beslenme Modeli}

Hipertansiyonu Durdurmaya Yönelik Diyet Yaklaşımı (Dietary Approaches to Stop Hypertension [DASH]) olarak adlandırılan beslenme modeli, toplam yağ, doymuş yağ, kolesterol ve sodyum içeriğinin düşük olması; buna karşılık kalsiyum, potasyum, magnezyum mineralleri ile lif ve protein içeriğinin yüksekliği ile dikkat çeken bir beslenme modelidir (31). Diyabetli bireylerde hipertansiyon riski daha yüksektir. Ayrıca bu beslenme modelinin pratik, özel gıda veya supleman gerektirmeyen ve tüm aile bireyleri tarafindan uygulanabilir bir model olması da avantajları olarak sıralanmaktadır (32).
Shirani et al. (33) tarafından DASH diyetinin glisemik kontrol üzerine etkilerinin değerlendirildiği bir meta analizde, 16 haftadan uzun süre takip edilen hastaların açlık insülin düzeylerinin DASH grubunda anlamlı şekilde azalabileceği saptanırken, aynı meta analizde açlık kan glukozu ve insülin direncinin tahmininde homeostaik model değerlendirmesi (Homeostasis Model Assessment of Insulin Resistant [HOMA-IR]) düzeylerinde gruplar arasında anlamlı değişiklik gözlenmemiştir. DASH diyetinin tip 2 diyabette hipertansiyona etkisini araştıran bir başka çalışmada, DASH diyeti (25-30 kkal/kg/gün, \%55 KH, \%18 protein, \%27 yağ) uygulayan gruba $(n=20)$ aynı zamanda haftada 5 gün 15-20 dk. yürüyüş önerilmiştir. Kontrol grubuna $(n=20)$ ise ADA önerilerine göre beslenme tedavisi (25-30 kkal/kg/gün, \%50-60 KH, \%10-20 protein, \%25-30 yağ) uygulanmıştır. Dört haftalık takip sonrasında sistolik ve diyastolik kan basıncı vaka grubunda anlamlı şekilde azalırken; açlık kan glukozu, HbA1c ve lipit profili açısından 2 grup arasında anlamlı fark saptanmamıştır (34). Tip 1 diyabette DASH diyetinin glisemik kontrole olan etkisini değerlendirmek amacıyla yaptıkları çalışmada Peairs et al. (35), tip 1 diyabetli adolesan bireyleri, sürekli glukoz monitorizasyon sistemi (Continuous Glucose Monitoring System-CGMS) ile üçer günlük sürelerle izlemişler ve çalışma sonunda glisemik değişkenlik açısından diyabete modifiye DASH diyeti ve mevcut beslenme modeli arasinda anlamlı bir fark saptanmadığını bildirmişlerdir.

\section{Akdeniz Tipi Beslenme Modeli}

$\mathrm{Bu}$ beslenme modelinde karakteristik olarak, bol miktarda sebze, meyve, baklagil, kuruyemiş, balık ve zeytinyağı tüketimi vardır; süt ürünleri ve şarabın ılımlı tüketimi önerilirken; tereyağı, krema, şekerli yiyecek ve içecekler ile kırmızı ve işlenmiş etlerin tüketimi azaltılmıştır (36,37).

Sleiman et al. (38), inceledikleri çalışmaların çoğunda Akdeniz diyetinin glisemik kontrol ve kardiyovasküler hastalıklar (KVH) üzerinde olumlu etkilerinin gösterildiğini vurgulamışlardır (38). Koloverou et al. (39), 10 yıllık izlem sonucunda 
Akdeniz beslenme modeline uyumlu olan bireylerde diyabet riskinin uyumsuz olanlara kıyasla \%62 oranında daha düşük olduğunu bildirmişlerdir. Diyet polifenolleri, kimyasal yapıları nedeniyle, özellikle glukoz homeostazı ile ilgili moleküler yolaklarla etkileşerek çoklu biyoaktiviteler sergilemektedirler. $\mathrm{Bu}$ nedenle Akdeniz diyetinin insülin direnci ve tip 2 diyabet üzerine olumlu etkilerinin polifenollerden kaynaklandığı düşünülmektedir (36). Bir başka derlemede ise Akdeniz diyetinin içerdiği biyoaktif besin bileşenleri ve fitokimyasalların, metabolik yolaklar üzerindeki sinerjik etkileri nedeniyle metabolik sendrom, tip 2 diyabet ve KVH riskini azalttığı belirtilmektedir (40).

Tüm bu olumlu etkilerin yanı sira diyabet ve Akdeniz tipi beslenme modeli etkileşimleri üzerine son ylllarda yapılan araştırmalarda, Akdeniz tipi beslenmenin prediyabet ve diyabetli hastalarda endotel fonksiyonunu iyileştirdiği (41), yeni tanı almış tip 2 diyabetli hastalarda, düşük yağlı diyetle kıyaslandığında da subklinik ateroskleroz progresyonunun önlenmesi ile ilişkili olduğu saptanmıştır (42).

Düşük yağlı, vejetaryan, Akdeniz, yüksek proteinli, orta KH'li, düşük KH’li, düşük glisemik indeksli/ glisemik yüklü ve Paleolitik beslenme modellerinin tip 2 diyabette glisemik kontrole etkilerini değerlendiren bir meta analizde, tüm beslenme yaklaşımlarında kontrol grubuna göre HbA1c ve açlık kan glukozunun anlamlı şekilde düşük olduğu saptanmıştır. Bahsi geçen beslenme yaklaşımları arasında ise Akdeniz diyetinin glisemik kontrolü iyileştirmek için en etkili diyet yaklaşımı olduğu belirlenmiştir (43).

Diyabet Kanada'nın (Diabetes Canada) kanıta dayalı olarak yayınladığı 2018 kılavuzuna göre, Akdeniz tipi beslenme modeli ciddi kardiyovasküler (KV) olayları azaltır (kanıt düzeyi A), glisemik kontrolü iyileştirir (kanıt düzeyi B); vejetaryen ya da vegan beslenme glisemik kontrolü iyileştirir (kanıt düzeyi B), vücut ağırlığı (kanıt düzeyi C), LDL kolesterol (kanıt düzeyi B) ve miyokardiyal enfarktüs riskini (kanıt düzeyi B) azaltır, DASH beslenme modeli glisemik kontrolü iyileştirir (kanıt düzeyi C), kan basıncını (kanıt düzeyi D), LDL kolesterolü (kanıt düzeyi B) ve ciddi KV olayları (kanıt düzeyi B) azaltır. Kılavuza göre, her üç diyetin de diyabet ve KV hastalık yönetiminde rolü bulunmaktadır. Ayrıca özellikle çok düşük KH'li diyetlerin ketojenik etkilerinin, özellikle insülin ya da Sodyum Glukoz Transporter 2 (SGLT2) inhibitörleri kullananlar için ve glukagonun hipoglisemi tedavisindeki etkinliği açısından endişe verici olduğu vurgulanmıştır (44). Diyabetin Önlenmesi ve Tedavisinde Kanita Dayalı Beslenme Tedavisi Rehberi-2019' da düşük ya da çok düşük KH’li diyetlerin, vitamin, mineral, posa alımını ve enerji kaynağı olan çok fazla sayıda besinin tüketimini sınırlandırması, enerjinin protein, yağdan ve doymuş yağdan karşılanan oranlarının önerilen düzeylerin üzerinde alınmasına neden olması, uzun dönemli etkilerini gösteren çalışmaların sınırlılığı nedeniyle önerilmemesi gerektiği bildirilmiştir (15).

\section{SONUÇ VE ÖNERILLER}

Sonuç olarak, diyabetik bireylerde düşük KH'li diyetlerin rolü hala net değildir. Akdeniz, DASH ve bitkisel bazlı diyetler, araştırmalarda saptanan olumlu sonuçları nedeniyle sağlıklı beslenme modellerine örnektir ancak, bireyselleştirilmiş beslenme planı, belirli beslenme modellerinin önerilmesinden ve uygulanmasından ziyade kişisel tercihler, ihtiyaç ve hedefler üzerine odaklanmalıdır.

Çıkar çatışması - Conflict of interest: Yazarlar çıkar çatışması olmadığını beyan ederler. - The authors declare that they have no conflict of interest.

\section{KAYNAKLAR}

1. Yamada S. Paradigm shifts in nutrition therapy for type 2 diabetes. Keio J Med. 2017;66:33-43.

2. Rabinowitch IM. Experiences with a high carbohydratelow calorie diet for the treatment of diabetes mellitus. Can Med Assoc J. 1930;23:489-98.

3. Leslie WS, Taylor R, Harris L, Lean ME. Weight losses with low-energy formula diets in obese patients with and without type 2 diabetes: systematic review and meta-analysis. Int J Obes (Lond). 2017;41:96-101. 
4. Henry RR, Scheaffer L, Olefsky JM. Glycemic effects of intensive caloric restriction and isocaloric refeeding in noninsulin-dependent diabetes mellitus. J Clin Endocrinol Metab. 1985;61:917-25.

5. Taylor R. Banting Memorial lecture 2012: reversing the twin cycles of type 2 diabetes. Diabet Med. 2013;30:26775.

6. Taylor R. Type 2 diabetes: etiology and reversibility. Diabetes Care. 2013;3:1047-55.

7. Lim EL, Hollingsworth KG, Aribisala BS, Chen MJ, Mathers JC, Taylor R. Reversal of type 2 diabetes: normalisation of beta cell function in association with decreased pancreas and liver triacylglycerol. Diabetologia. 2011; 54: 2506-14.

8. Murakami R, Saisho Y, Watanabe Y, Inaishi J, Tsuchiya $\mathrm{T}$, Kou K, et al. Pancreas fat and $\beta$ cell mass in humans with and without diabetes: an analysis in the Japanese population. J Clin Endocrinol Metab. 2017;102:3251-60.

9. Henry RR, Gumbiner B. Benefits and limitations of verylow-calorie diet therapy in obese NIDDM. Diabetes Care. 1991;14:802-23.

10. Vertes V. Very low calorie diets--history, safety and recent developments. Postgrad Med J. 1984;60:56-8.

11. Lean ME, Leslie WS, Barnes AC, Brosnahan N, Thom G, McCombie L, et al. Primary care-led weight management for remission of type 2 diabetes (DiRECT): an open-label, cluster-randomised trial. Lancet. 2018;391:541-51.

12. Gregg EW, Chen H, Wagenknecht LE, Clark JM, Delahanty LM, Bantle J, et al. Look AHEAD Research Group. Association of an intensive lifestyle intervention with remission of type 2 diabetes. JAMA. 2012;308:2489-96.

13. IDF Clinical Practice Recommendations for managing Type 2 Diabetes in Primary Care-2017. Available at: https://www.idf.org/e-library/guidelines/128-idfclinical-practice-recommendations-for-managing-type2-diabetes-in-primary-care.html. Accessed October 5,2018.

14. American Diabetes Association. Lifestyle Management: Standards of Medical Care in Diabetes-2018. Diabetes Care 2018; 41: S38-S50.

15. Diyabet Diyetisyenliği Derneği. Diyabetin Önlenmesi ve Tedavisinde Kanita Dayalı Beslenme Tedavisi Rehberi-2019. Armoni Nüans Baskı Sanatları A.Ş. Nisan 2019, İstanbul.

16. Snorgaard O, Poulsen GM, Andersen HK, Astrup A. Systematic review and meta-analysis of dietary carbohydrate restriction in patients with type 2 diabetes. BMJ Open Diabetes Res Care. 2017;5:e000354.

17. Tay J, Thompson CH, Luscombe-Marsh ND, Wycherley TP, Noakes M, Buckley JD, et al. Effects of an energyrestricted low-carbohydrate, high unsaturated fat/low saturated fat dietversus a high-carbohydrate, low-fat diet in type 2 diabetes: A 2-year randomized clinical trial. Diabetes Obes Metab. 2018;20:858-71.

18. Tay J, Thompson $\mathrm{CH}$, Luscombe-Marsh ND, Noakes M, Buckley JD, Wittert GA, et al. Long-term effects of a very low carbohydrate compared with a high carbohydrate diet on renal function in individuals with type 2 diabetes: A randomized trial. Medicine (Baltimore). 2015;94:e2181.

19. Sylvetsky AC, Edelstein SL, Walford G, Boyko EJ, Horton ES, Ibebuogu UN, et al.:Diabetes Prevention Program Research Group. A high-carbohydrate, high-fiber, lowfat diet results in weight loss among adults at high risk of type 2 diabetes. J Nutr. 2017;147:2060-66.

20. Lindström J, Peltonen M, Eriksson JG, Louheranta A, Fogelholm M, Uusitupa M, et al. High-fibre, low-fat diet predicts long-term weight loss and decreased type 2 diabetes risk: the Finnish Diabetes Prevention Study. Diabetologia. 2006;49:912-20.

21. Miller CK. For newly diagnosed type 2 diabetes, a lowcarbohydrate Mediterranean diet may delay need for medication and improve chance of remission compared to a low-fat diet. Evid Based Nurs. 2015;18:74.

22. Meckling KA, O’Sullivan C, Saari D. Comparison of a low-fat diet to a low-carbohydrate diet on weight loss, body composition, and risk factors for diabetes and cardiovascular disease in free-living, overweight men and women. J Clin Endocrinol Metab. 2004;89:2717-23.

23. Guldbrand H, Lindström T, Dizdar B, Bunjaku B, Östgren CJ, Nystrom FH, et al. Randomization to a low-carbohydrate diet advice improves health related quality of life compared with a low-fat diet at similar weight-loss in Type 2 diabetes mellitus. Diabetes Res Clin Pract. 2014;106:221-7.

24. Jonasson L, Guldbrand H, Lundberg AK, Nystrom FH. Advice to follow a low-carbohydrate diet has a favourable impact on low-grade inflammation in type 2 diabetes compared with advice to follow a low-fat diet. Ann Med. 2014;46:182-7.

25. Barnard ND, Katcher HI, Jenkins DJ, Cohen J, TurnerMcGrievy G. Vegetarian and vegan diets in type 2 diabetes management. Nutr Rev. 2009;67:255-63.

26. Craig WJ, Mangels AR. American Dietetic Association. Position of the American Dietetic Association: Vegetarian diets. J Am Diet Assoc. 2009;109:1266-82.

27. Agnoli C, Baroni L, Bertini I, Ciappellano S, Fabbri A, Papa M, et al. Position paper on vegetarian diets from the working group of the Italian Society of Human Nutrition. Nutr Metab Cardiovasc Dis. 2017;27:1037-52.

28. Barnard ND, Cohen J, Jenkins DJ, Turner-McGrievy G, Gloede L, Green A, et al. A low-fat vegan diet and a conventional diabetes diet in the treatment of type 2 diabetes: a randomized, controlled, 74-wk clinical trial. 
Am J Clin Nutr. 2009;89:1588S-1596S.

29. Barnard ND, Levin SM, Gloede L, Flores R. Turning the Waiting Room into a Classroom: Weekly Classes Using a Vegan or a Portion-Controlled Eating Plan Improve Diabetes Control in a Randomized Translational Study. J Acad Nutr Diet. 2018;118:1072-79.

30. Kahleova H, Hrachovinova T, Hill M, Pelikanova T. Vegetarian diet in type 2 diabetes--improvement in quality of life, mood and eating behaviour. Diabet Med. 2013;30:127-9.

31. Challa HJ, Uppaluri KR. DASH Diet (Dietary Approaches to Stop Hypertension) StatPearls. Treasure Island (FL): StatPearls Publishing; 2018-.2018 Sep 21. Available at: $\quad$ https://www.ncbi.nlm.nih.gov/pubmed/29494120. Accessed: October 5, 2018.

32. Campbell AP. DASH Eating Plan: An eating pattern for diabetes management. Diabetes Spectr. 2017;30:76-81.

33. Shirani F, Salehi-Abargouei A, Azadbakht L. Effects of Dietary Approaches to Stop Hypertension (DASH) diet on some risk for developing type 2 diabetes: a systematic review and meta-analysis on controlled clinical trials. Nutrition. 2013;29:939-47.

34. Paula TP, Viana LV, Neto AT, Leitão CB, Gross JL, Azevedo MJ. Effects of the DASH diet and walking on Blood Pressure in Patients with Type 2 Diabetes and uncontrolled hypertension: a randomized controlled trial. J Clin Hypertens (Greenwich). 2015;17:895-901.

35. Peairs AD, Shah AS, Summer S, Hess M, Couch SC. Effects of the dietary approaches to stop hypertension (DASH) diet on glucose variability in youth with Type 1 diabetes. Diabetes Manag (Lond). 2017;7:383-91.

36. Guasch-Ferré M, Merino J, Sun Q, Fitó M, Salas-Salvadó J. Dietary polyphenols, Mediterranean diet, prediabetes, and type 2 diabetes: a narrative review of the evidence. Oxid Med Cell Longev. 2017;2017:6723931.
37. Emenaker NJ, Vargas AJ. The Mediterranean diet, the OGG1 gene, and disease risk: Early evidence. J Acad Nutr Diet. 2018;118:547-49.

38. Sleiman D, Al-Badri MR, Azar ST. Effect of mediterranean diet in diabetes control and cardiovascular risk modification: a systematic review. Front Public Health. 201528;3:69.

39. Koloverou E, Panagiotakos D, Pitsavos C, Georgousopoulou E, Chrysohoou C, Skoumas I, et al. Mediterranean diet and ten-year type 2 diabetes risk. Potential mediation of the relationship from inflammatory factors: Results from ATTICA study (20022012). Clin Nutr ESPEN. 2016 Jun;13:e57.

40. Salas-Salvadó J, Guasch-Ferré M, Lee CH, Estruch R, Clish CB, Ros E. Protective effects of the Mediterranean diet on type 2 diabetes and metabolic syndrome. J Nutr. 2016; 146:920-27.

41. Torres-Peña JD, Garcia-Riosa A, Delgado-Casado N, Gomez-Luna P, Alcala-Diaz JF, Yubero-Serrano EM, et al. Mediterranean diet improves endothelial function in patients with diabetes and prediabetes: A report from the CORDIOPREV study. Atherosclerosis. 2018;269:50-6.

42. Maiorino MI, Bellastella G, Petrizzo M, Gicchino M, Caputo M, Giugliano D, et al. Effect of a Mediterranean diet on endothelial progenitor cells and carotid intimamedia thickness in type 2 diabetes: Follow-up of a randomized trial. Eur J Prev Cardiol. 2017;24:399-408.

43. Schwingshackl L, Chaimani A, Hoffmann G, Schwedhelm C, Boeing H. A network meta-analysis on the comparative efficacy of different dietary approaches on glycaemic control in patients with type 2 diabetes mellitus. Eur J Epidemiol. 2018;33:157-70.

44. Sievenpiper JL, Chan CB, Dworatzek PD, Freeze C, Williams SL.: Diabetes Canada Clinical Practice Guidelines Expert Committee. Nutrition therapy. Can J Diabetes. 2018;42:S64-S79. 